\title{
INCLUSIVIST SOTERIOLOGY \\ MOUHANAD KHORCHIDE'S ISLAMIC THEOLOGY OF MERCY AND ITS CONTRIBUTION TO INTER-FAITH DIALOGUE
}

\begin{abstract}
Katharina Völker*
This article explores the salvific prospects of 'non-Muslims' alluded to in the 'theology of mercy' (TM) as proposed by the Austrian-Palestinian Islamic scholar Mouhanad Khorchide. A critical description of his thoughts on belief, salvation and 'being Muslim' outlines a possible concept (whether dialogical, pluralistic or inclusivist) of salvation applicable to the religious and non-religious Other. The significance of his theological-humanistic project must be understood within the pedagogic setting of Khorchide's intellectual action, namely the state university training of future Muslim school educators in Germany. The essay argues that Khorchide promotes an inclusivist view of salvation, as well as of the perfection of humanhood which necessitates 'love-action-harmony' and dialogical collaboration between both God and humans, as well as among the whole of humanity. Finally, I reflect on the potential contribution of $\mathrm{TM}$ to inter-religious (inter-human) dialogue along the lines of Catherine Cornille's five pillars.
\end{abstract}

* Centre for Islamic Theology - University of Tübingen.

This research is supported by the

German Ministry of Education and Research (BMBF).

Keywords: inclusivism, inter-religious dialogue, Islamic theology, Mouhanad Khorchide, perfection of humankind, pluralism, religious other, salvation, soteriology, love, mercy 
page 2 of 31

\section{Mouhanad Khorchide}

In 2014, at the Theological Forum Christentum-Islam in Stuttgart, I first became aware of Mouhanad Khorchide's contribution to what he describes as "a modern Islamic theology and new humanism." ${ }^{\text {1 }}$ There, on the $10^{\text {th }}$ anniversary of this esteemed platform for engagement in inter-faith dialogue, scholars discussed possible opportunities arising from the convergence of theology and science. Opportunities were given for the critique of religious tradition, the reconciliation between revelation, religious experience and reason, the practice of scientific theology, and more. Since then I have found, in Khorchide's work and scholarly reflections, much that demands consideration. This chapter addresses his thoughts on the salvation of the Other - a concept which, for him, includes not merely the 'religious' Other.

Khorchide teaches Islamic Pedagogy at the University of Münster and publishes widely on his so-called "fresh look" at the Quran and Islam. He is deemed by his supporters to be a reformative Islamic theologian and has been compared to the sixteenth century reformer Martin Luther. For others he is a heretic and not fit for his post. For those who are familiar with progressive Islamic theology in the West, Khorchide's approach to Islam is comparable with that of Fazlur Rahman, Nasr Hamid Abu Zayd, Ömer Özsoy, and those to whom the term neo-Mu'tazilist [Hildebrandt 2007] is ascribed. ${ }^{2}$ Such contemporary intellectuals often argue for rational and independent thinking (ijtihād), a return to the legacy of Averroes, and a focus on the Qur'ān as the primary source for discernment, together with the reform of education in other areas of socio-political importance.

1 I was privileged to accompany Douglas Pratt on my first visit to this academic event during my parental leave, in an attempt to mentally get back into academia. Doug Pratt was my prospective New Zealand Ph.D Supervisor in 2008 and, despite Greg Dawes taking over this task eventually, Doug has turned out to be a steadfast mentor up to the present day. As for my recent research project at Tübingen University, as well as hopefully for future intellectual endeavours, I am grateful for his insight into the realm of religious studies academia, and his dear friendship.

2 The term Neo-Mutazilism expresses the difficulty to discern how accurately, or to which extent, modern thinkers actually refer to the thoughts of the classic Mutazila. See, for example, Hildebrandt's discussion: "Between Mu'tazilism and Mysticism. How much of a Mu'tazilite is Nasr Hâmid Abû Zayd?," in A Common Rationality, pp. 495-512 [Hildebrandt 2007a] 
page 3 of 31

To better relate to Khorchide's work it is essential to look at the background to his academic undertaking. Since 2010 it has been the policy of the Federal Republic of Germany to address a need for the teaching of Islamic theology in public universities [Fuess 2011] [Wissenschaftsrat 2010]. Up to 2018, four centres with confessional teaching chairs had been established at six universities. $^{3}$ The universities, in co-operation with German Muslim communities, provide for the academic training of future Islamic educators, theologians, imams, family counsellors, and social workers. Khorchide is therefore one of 17 staff appointed within the previous eight years to teach Islamic thought, at public universities, to future teachers and his chair the result of the declared policy of the Federal Government. This policy, modelled on existing Church-State arrangements, has not been without criticism and its implementation has not gone unchallenged, since the theological training is required not only to meet the confessional criteria of each faith community but also be in accordance with federal law and the standards of academic teaching and research [Spriewald 2003] [Unruh 2009] [Völker 2014a] [Völker 2014b]. As a result, Khorchide's chair is subject to certain constraints. Although my article will not be focus on these often rather political discussions, it is worth pointing out the complexity of the background to his teaching.

Nevertheless, his engagement in academic and public discourse about Islam, as well as his outreach to laypersons, both Muslim and non-Muslim, has, during the last decade, produced an important body of work. The following investigation is based on his only monograph in English: 'Islam is Mercy' (2012), which seeks to base Islamic theology and pedagogy on mutual love between God and creation. Other significant monographs are: "Scharia, der missverstandene Gott. Der Weg zu einer modernen islamischen Ethik" [Sharia. The Misunderstood God. The Way to Modern Islamic Ethics] (2013) and "Gott glaubt an den Menschen: Mit dem Islam zu einem neuen Humanismus" [God Believes in Humankind. With Islam towards a New

3 In 2019 the Federal Ministry of Education and Research plans to finance further staff at the newly established Institute for Islamic Theology at Humboldt University [Warnecke 2018]. 
Humanism] (2015). These monographs are programmatic for Khorchide's project of humanising Islamic theology and are written with a wide audience in mind: academics, students, and the general reading public (see also [Khorchide 2011] [Khorchide 2010a] [Khorchide 2010b]). For the purpose of this essay, the relevant articles and the two additional books are viewed in the context of his theology of mercy as presented in 'Islam is Mercy,' as well as with a focus on salvific outlooks.

I have chosen to concentrate on Khorchide and his work since he, in comparison with his contemporaries holding chairs in Islamic thought and teaching in German public universities, has produced the largest corpus of writings on this subject. His publications promote an open-minded Islam and are written from a theological perspective modified by his experience of life. This perspective can be contrasted with that of one of his intellectual predecessors, Muhammad Arkoun, a self-acclaimed islamologist, who, in his Western writings, mostly refrained from personalised formulations [Völker 2017; 186]. Similar to Hasan Hanafi and Nasr Hamid Abu Zayd, Khorchide attempts to offer ideas for long- term reformative projects from a care-taking and confessional point of view [McCutcheon 2001]. Despite accusations of heresy against him (as have also been uttered against Hanafi, Arkoun and Abu Zayd), ${ }^{4}$ he is, in my view, a legitimate participant in the discourse about Islam from within Islam. He is one who identifies himself as Muslim and whose work demonstrates a passionate desire to participate in academic and public discussions, both within and outside Islam, as to what Islam intends the contemporary world to be and what it then means to be a Muslim. Khorchide's work is therefore of the greatest interest to those who are students of contemporary Islam and also provides a critique of the views about Islam promulgated both from within, and outside of, academic circles.

Khorchide of necessity addresses the challenges faced by Muslims who live in non-Islamic and largely secularised environments and who still seek to

\footnotetext{
4 Accusations of heresy are often based on the charge of bid'ah (Engl.: innovation) and several reformists have been accused of promoting forbidden theological innovation, which has then lead to charges of heresy and apostasy.
} 
page 5 of 31

maintain their own religious identities and practices within societies which are aggressively secular, neo-liberal, and capitalistic. Khorchide's own days have largely been lived in such an environment. He is a child of the Palestinian Diaspora. He was born in the Lebanon and educated in the Lebanon, Saudi Arabia, and Austria and now lives in Germany and weaves anecdotes of life into the fabric of his writings. Khorchide is one who crosses borders, geographically, academically, and mentally.

Khorchide therefore belongs among the contemporary Islamic scholars (be they revivalist, reformist, progressive, fundamentalist, liberalist, humanist etc.) who look at Islam from within, but who do not emphasise its cultural, ethnic, or national forms. Rather, he views Islam as addressing global society [Kersten 2011], and proposes a deculturalised form of his religion, with the Qur'ān as its primary text and subject of exegesis. ${ }^{5}$ His personal project can be seen as the consequence of intellectual internationalisation and globalisation which has resulted in an individualised conceptualisation of Islamic beliefs. Similar observations concerning the transformation of Islamic beliefs have been made by Cesari [2003], Bendixsen [2013], Nökel [2002] and Klinkhammer [2003]. One can therefore, expect, in the realm of the nonIslamic world, a wide diversity of theological views among the holders of chairs of Islamic theology in, for example, German universities. These views are the result of individual study, training, reflection, and life-experience in the eleven nations from which the holders of the chairs have been drawn. They are representative of the pluralistic nature of the Muslim presence in contemporary Germany.

\footnotetext{
Khorchide - like his predecessors Hanaf, Majid, Abu Zayd, Arkoun, Rahman, among others -refers to secondary sources and hence utilises sira, ahadith, sunna, figh etc. Although their focus is on the Qur'ān as the primary source, they are not declared Qur'ānists (qu'rânoon, ahl al qu'rân). Fazlur Rahman, for example, sought to refrain from the intellectual battles between the ahl al qu'rân and ahl al hadith in Pakistan.
} 


\section{Theology of Mercy (TM)}

Khorchide's application of the current understanding of Islamic sources, especially the Qur'ān, to contemporary Islam, can be placed alongside the progressive and liberal thinking of such people as Amina Wadud, Farid Esack, Nasr Hamid Abu Zayd, and Muhammad Arkoun. These intellectual endeavours are characterised by a close reading of the Qur'ān, critical reflections on secondary Islamic sources and clerical authority. ${ }^{6}$ Korchide proposes bringing about gradual change within the Islamic world in its understanding of what it means to be a Muslim, particularly within societies in which the culture is western and in which Muslims are a minority. How Khorchide's theological views, and the nature of their underlying principles, shape his contribution to the debate concerning the salvation of non-Muslims and its implication for dialogue with the majority of that world, must now be examined.

Khorchide views creation as a consequence of divine mercy, God's main attribute, which impels the Divine to be close to the entire creation and not solely to Islam as a privileged minority within it [Khorchide 2013a; 35]. The Divine is connected to humanity through revelation, inspiration, and the commissioning of prophets, establishing a dialogue with humans through their intellectual capabilities, limited only by social, cultural, psychological, and other factors. The Divine patiently guides humankind according to their capabilities for the achievement of God's purposes through ru'yā (dream face) or ḥulm (dream), waḥy (inspiration), natural ayāt (signs of nature

\footnotetext{
$6 \quad$ To emphasize the need to revisit religious heritage and scripture in order to find answers for our daily actions in the world, Khorchide frequently mentions Ghazali's project of reviving the religious sciences [Khorchide 2015].
} 
page 7 of 31

demonstrating divine intent), ${ }^{7}$ as well as by the recitation of the Quran. ${ }^{8}$ Therefore the Divine applies a patient pedagogy by which humankind ought to be guided according to its capabilities [Khorchide 2013a; 40-44, 63, 74]. Should these forms of instruction not be heeded, and the sinner experiences infernal retribution, even there in 'the place of fire' he or she is transformed through God's ever merciful offer of forgiveness [Khorchide 2013a; 47-56]. This eternal offer of renewal of the covenant made between God and the individual (mīthāq, cf. Q 7:172-3), gives meaning to the promise of liberation which is inherent in Islam. ${ }^{9}$ This promise allows humanity to indulge its own creative instinct and powers to shape God's creation. We are reminded here of

The idea that there are other means by which God shares divine wisdom with humanity often relates to the saying that the Quran does not contain the entire words of God as exemplified in 31:27 "And if whatever trees upon the earth were pens and the sea [was ink], replenished thereafter by seven [more] seas, the words of Allah would not be exhausted. Indeed, Allah is Exalted in Might and Wise." Other texts in the Quran claim the need for "proper thinking" and reflection on worldly phenomena such as natural ayāt. The following verses, for example, speak against naql (blind adherence): 2:170 + 7:28, 5:104, 31:21, 43:22-24. Moreover, Nasr Hamid Abu Zayd understands the communication between God and creation as revolving around the idea of divine signs. Such signs should be witnesses for the divine origin of God's creation. Abu Zayd understands the inspirations to Muhammad also as signs from God. With reference to Ibn Arabi, Abu Zayd understands the Quran and the entire creation as a sign (ayāt) from God. While natural signs are visible for all humans who wish to understand creation, revelation, as oral text, is in need of a nabi (Messenger) who receives the signs and communicates them to an audience. Basically, Abu Zayd maintains, all people should be able to understand the Quranic signs (ayāt) [Völker 2017; 87].

8 Compare: "We shall show them Our signs in the horizons and in themselves, till it is clear to them that it is the truth. Suffices it not as to thy Lord, that He is witness over everything?" Q 41:53 [Arberry 1996]. Reciting the Quran is thought of as a correspondence between the reciter and the Divine. The spirit, words and aesthetics of the Quran have here the potential to give answers to the believer's heart, comparable to a call/response interaction (Kermani, 2000).

9 In the view of the Mutazila and Shii theologians from the 11th century onward, and of other Muslim scholars, rather than referring to any primordial event, Q 7:172-3 should be interpreted allegorically as alluding to an ongoing, universal compact: human beings are obliged, once they reach maturity, to believe in God and to acknowledge His unity. This obligation stems from their fitra or from the prophetic messages that have been delivered to mankind throughout history (for these and other interpretations of $Q 7: 172-3$, see Gramlich; Gobillot, 46-53, 62-65) [Ebstein 2014]. Khorchide writes about 7:157/172:God is the source of His plan of mercy, which includes the eternal election of humanity as divine beings. At the same time, this plan encompasses the historical implementation and expression of this election, as well as its eschatological accomplishment. Within the framework of this plan, God (through creation) forms a bond with all human beings. "And when your Lord brought forth from the loins of the Children of Adam their posterity and made them testify against themselves. [He said]: 'Am I not your Lord?' They said, 'Yes, we testify'” [Khorchide 2014a; §10.6; 55.7]. 
page 8 of 31

Aquinas's process theology, ${ }^{10}$ and also of Paolo Freire's liberation theology. ${ }^{11}$ Khorchide's constant emphasis on human free will and thought recalls Freire's teaching that freedom is the consequence of critical reflection on established structures and hierarchies. For Khorchide free will is necessary for both the acquisition and the maintenance of God's eternal love and counsel.

(A)nyone who commits to divine love and mercy and demonstrates this through his or her actions is a Muslim, even if the person does not consciously believe in God and remains in a state of fițra; it is not the labels 'believer' or 'non-believer' God cares about. [...] In turn, anyone who only verbally claims to believe in God, but whose actions fail to show evidence of love and mercy, is not a Muslim. The Prophet Muhammad expresses this as follows: "He who does not wish for his brother what he wishes for himself is not a believer," and, "He who sleeps on a full stomach but knows his neighbour to suffer from hunger does not believe in my message." [Khorchide 2013b; §24.6;155.1 $]^{12}$

Therefore it would seem that Khorchide's theology presents soteriological inclusivism via salvation achieved through co-operation among humanity. This is primarily an openness to love, whether or not one recognises love as both an endowment from God and prime attribute. Admitting love and allowing it to affect one's heart is followed by incorporating the heart's new state into immediate action-such is the transformative power of love. Being Muslim in this broad sense will alter the terminologies of belief, non-belief, and nonbeliever. In the context of Islam, the normal significance of the term Muslim, namely, 'being a confessed Muslim and member of the umma', no longer suffices. Khorchide's realisation of this has the consequence that it is not

10 Thomas Aquinas recognised human reason as the basic means of arguing with other faiths, since the need for reasoned reflection could be found across religious traditions (cf. Raimundus Lullus) [Pratt 2017; 20].

11 Paolo Freire, similar to Fanon, Sartre and, in parts, Hegel, maintained that creative thought is linked to processes of liberation. In this respect we find parallels to the Islamic adab, which is a holistic approach to education with the potential to create what Arkoun calls a new ethos of tolerance and solidarity among cultures. Aspects of adab include openness towards various, (also non-Islamic) sources of knowledge, the surpassing of religious borders, and the liberalization of thinking from doctrines and orthodoxies, which should result in renewal and creativity, aspects which seem to find endorsement with Khorchide [Völker 2018; 20].

12 Khorchide refers here to al-Bukhārī, hadith no. 13., and aț-Ṭabarāni, al-Jāmi' al-Kabīr, hadith no. 750 respectively. See also Khorchide's reference to the Quranic understanding of who is a Muslim in Khorchide [2014b]. 
page 9 of 31

recognised membership of a Muslim community, that is membership in a narrow sense, but good deeds arising from a loving heart that has become the primary identifying mark of a Muslim. We could call this latter distinctness a broad-sense definition of being Muslim. The broad-sense definition therefore incorporates more people than those who meet recognised criteria. The broadsense definition includes all who consciously identify as Muslim but also those whose acts towards others and the world at large are in harmony with their love for them and it. Accusations of heresy and apostasy within the Islamic world are thus rendered impossible since those charges are created by disputes over the meaning and implications of the text of the Qur'ann, such as God's attributes are eternal or finite, whether the Qur'ān is created or uncreated, whether the Prophet Muhammad is of divine character or a fallible human being, and so on. In the broader sense defined by Khorchide the existence of God, or of the place of the Prophet Muhammad in the Islamic tradition, have no significance as far as being a Muslim is concerned. This acceptance is an inclusivist act which does not require the consent of others. On the other hand, Muslims in the narrow sense of that term might not be inclined to agree that belief in God and the Prophet Muhammad is not essential to membership of the community. Khorchide in fact tends to move between the two categories of narrow and broad without always making the distinction clear. When, however, he is involved in intra-Islamic debates concerning sharia law, rituals, and creed it is obvious that he is within the narrow context.

Khorchide's theology of mercy is based on the argument that God's main attribute is mercifulness and hence all intentions for creation stem from love and mercy. To also apply this parameter to humans seems ambitious. However, in order to also argue for humans having to espouse to this universal mercifulness, Khorchide makes reference to Ghazali's call for modeling one's soul on God's attributes such as forgiveness, mercifulness, accepting repentance etc..$^{13}$

${ }_{13}$ Ghazali identifies God's attributes as they are reflected in the names of God, i.e. the 'One who accepts remorse (at-Tawwāb)‘ [Khorchide 2015; §8.21; 127.9]. 
page 10 of 31

In a further step Khorchide dispels Ghazali's inclination to determine the belief in the Prophet Muhammad and His sayings as signs of true belief and warranty for salvation [Khalil 2007; 49]. ${ }^{14}$ In addition, he rejects Ghazali's categorisation of the saved and damned, which draws heavily on degrees of acceptance of the Prophet's status, miracles and sayings, and therefore bears crucial consequences for the perspective on non-Muslims. Naturally, Muslim philosophers and theologians have tackled this problem. Hassan Khalil for example, looking at Ghazali, Ibn Arabi, Ibn Qayyim al-Jawziyyah and his teacher Ibn Taymiyya, as well as Rashid Rida states:

And while none of them may be classified as Hickean-like, soteriological religious pluralists (despite some popular misconceptions regarding some of them), one especially contentious issue of debate has been whether adhering to the Message of Muhammad in particular, is absolutely necessary for salvation. This debate tends to revolve around the question: What does Islamic scripture indicate about the fate of those who have not been 'properly' exposed to the Message of the Messengers? (Even if "every community has been sent a warner" [Q. 35:24], this need not mean either that every individual has received a Message or that each community has preserved its original Message). And what of those who are 'sincere' yet choose to reject the Message because they do not find it convincing? What role do Divine justice and mercy play in all of this? [Khalil 2007; 15]

TM attempts to answer these questions. For Khorchide the main rule for living a godly life is to harmonise God's love and mercy with one's soul and acts. This proposed harmony between a commitment to love and mercy and to meritorious acts is not, however, without moral connotations and is therefore not arbitrary. The assignment of qualitative moral values is still to be made but Khorchide does not enter into a discourse about morality. Nevertheless, he proposes harmony between commitment and actions as a criterion for entry into God's presence. Khorchide is replacing a call for 'harmony between belief and action,' with a 'commitment to love and action,' without the requirement of assent to a particular creed. If, however, we take a closer look at the

${ }_{14}$ Compare with Abu Hamid al-Ghazali's The Decisive Criterion, in which he links belief and being Muslim to belief in God and the Prophet and all His reliable sayings; cf. [Griffel 2009; 106] Griffel refers to The Decisive Criterion and rightly points out Ghazali's adaption of Avicenna's prophetology, cf. Fazlur Rahman's PhD thesis on Avicenna's psychology [Rahman 1952]. 
page 11 of 31

context of this 'commitment to love and action' in this world, we see that it by no means dissolves into a mere intuition. Khorchide does not ignore the moral aspects of this commitment and postulates that its purpose is to provide justice for creation. ${ }^{15}$ This justice however operates within the frame of mercy: "God's mercy is not at odds with His justice; on the contrary, justice is one aspect of His mercy, meaning that His punishment also forms part of His mercy" [Khorchide 2014a; §7.1; 9.0]. Furthermore, Khorchide repeats that for the Mu'tazilites "justice meant basing actions on the good, performing them in people's interest. (...) (F)or the Mu'tazilites God's will represents justice" [Khorchide 2014a; $\$ 10.14 ; 63.0]$. He asserts that Justice is directed to the Good (a rather loose term) meaning either 'for the betterment of the people' or the equivalent to the 'common good' (maslaha), and that justice is the consequence of God's mercy and is in harmony with God's will and is indeed thus understood, at least to some degree, by women and men. To establish this connection between God's mercy and justice Khorchide refers mainly to the text of the Qur'ānic content and to selected hadith sayings. ${ }^{16}$ Thus Khorchide avoids being drawn into the Socratic dilemma for which Plato's Euthyphro could provide no solution: is it justice because God wills it or does God will justice because it is just [Burnet 1973; 2-16]. Does justice exist eternally next to the Divine (which would harm tawhid), or is it God's attribute? In the end Khorchide does not attempt to answer any of these questions, nor does he discover the essence of what it means to do good. His writings provide a definition of the Good as that which turns God's creation towards justice, operates in freedom, and aims at bringing benefit to all.

15 Khorchide refers to Fazlur Rahman in the context of the merciful justice principle of the Qur'ānic spirit. Other studies on the Qur'ān have also traced out justice as the primary goal of the Qur'ānic message, e.g.John Bouman, Gott und Mensch im Koran, 1977; Daud Rahbar, God of Justice: a Study in the Ethical Doctrine of the Qur'ān 1960.

16 "The contents of the Qur'ān serve the purpose of meeting people's interests in the world and the hereafter." In this context, "interests" does not convey randomness in the sense that everyone would be free to arbitrarily interpret the Qur'ān to please their own interests. By "interest" we mean nothing other than the implementation and realisation of love and mercy" [Khorchide 2014a; §42.7; 301.0]. There is too little juristic material in the texts to base a proper legal system on the Qur'ān,. This is also why Khorchide finds Rahman's double movement to be applicable in only a few cases, and instead he pleads for a broader hermeneutic with God's mercy, love and justice as its principal topics. 
page 12 of 31

Let's try to follow these thoughts so far. The commitment to love means to act from within love. The lover acts out this love towards the surrounding and makes decisions to act from within this state of affection, which will contribute to the betterment of creation. In this sense a Muslim is defined as someone who acts in accordance with her/his affection for the surrounding. A 'commitment to mercy,' as proposed by Khorchide, adds a more astute criterion to the definition of being Muslim. Mercy is for one, a conscious activity of one person in relation to another party and - in a religious context it may describe an act of a divine being towards creation. At this point questions arise about the nature of a relation between two parties where one acts mercifully towards the other (let's say on a horizontal level). On the vertical level the divine being releases mercy upon creation, emanates so to say 'downwards.' And this is not a possible reciprocal relation since God is self-sufficient. Thus we arrive here at two different natures of a merciful relation: the one among parties of creation, and the other being God's mercy towards creation. Let's turn to the first. In Khorchide's scenario, a participant in a merciful act must not necessarily believe in God and God's mercy in order to model her/his acts of mercy. Rather s/he 'knows' intrinsically how to act mercifully because s/he has opened her/him-self to love (not knowing or accepting that love originates in God). Love is hence provided by God like a stream of fresh water and whoever passes by can quench her/his thirst without having knowledge of the source of the spring.

The second level of 'interaction,' the vertical one, opens up two questions. If God is self-sufficient God does not depend on merciful acts by creation. However, in Khorchide's understanding the Divine works within creation through humankind. The acceptance of God's offer of love and mercy to humanity, 'enables' God to act within creation. This idea tends to rest on the assumption that God has decided to grant humans absolute free will and choice which the Divine does not choose to compromise by the will to partake in the ongoing creation. Hence TM neither serves occasionalism nor understands God as restricted by humans. It rather recognises that God has 
page 13 of 31

decided to work in the world based on humankind's free will and choice to either accept or reject the gift of mercy and love:

God does not directly intervene on Earth but acts through people - we serve as a medium for the realisation of divine love and mercy. One example is the healing of sick people by doctors and medicines, developed by human beings themselves. The more research on new therapeutic methods and medicines members of medical professions conduct, the more they act as a medium for God's intervention in the healing of patients. It follows that this is not an 'either-or' situation: is it God or a person who is at work? Is it God who heals the sick or a doctor? God co-operates with us; he realises His intentions through us, and we make them reality, without our freedom ever being compromised. The more perfect we become in this context, the greater God's opportunities to intervene. [Khorchide 2014a; §25.4; 163.3]

That God's love is available to all of creation independent of a conscious commitment to belief in the existence of God, does not answer questions of determinism. How is it that some people open up to the eternal and infinite love of God, and others do not? Why do some pass by the stream of God's love as if they are without any desire to slake their thirsts for it or even feel that thirst? What causes some to refuse God's love? For Khorchide one answer is 'self-centredness' -the product of an arrogance which hinders the access to God's love. Khorchide cites: "Whoever has an atom's worth of kibr (pride/arrogance) in his heart will not enter Paradise." ${ }^{17}$ Pride equates to the replacing of one's thankfulness and trust in the Divine with an unjustified selfassurance. We see here that Khorchide, by citing this hadith, steps outside the common debate about what constitutes a good Muslim, a believer, an infidel, a religious Other or any of the other variations of concepts trying to label 'not being a good Muslim.'18 The criterion for salvation rests instead on the state of

17 Abdullah ibn Mas'ud reports that Allah's messenger (peace be upon him) said: "Whoever has an atom's worth of kibr (pride and arrogance) in his heart will not enter Paradise." So a man said: What about a person who loves (i.e. takes pride in) wearing beautiful clothes and beautiful shoes? So he replied: "Indeed Allah is beautiful and loves beauty. Kibr is to reject the truth, and to despise the people." (Sahih Muslim, 1/65). Also Edmund Weber in his article on Allah's motherliness defines a kafirun as the denier of God's everlasting and alltime provided mercy [Weber 2003].

18 Khorchide's theology tries to refrain from normative discourses about authority to define Islam today. This is possible mainly due to the basis of 'love, mercy, justice, the common good,' which does not take on creedal formulae. Moreover, dialogue between God and humanity and its reflections upon human relationships does not allow for the exclusion of 
page 14 of 31

the heart. It becomes a question of recognising the stream of love and going with its flow towards the betterment of creation. ${ }^{19}$

Khorchide applies a broad sense to being a Muslim, as we have already seen, which does not require individuals to belong to a particular culture or society. This perspective, devoid of acculturation or membership of a particular group, but instead concentrating on the individual, allows him to base his theology on the individual person's relationship with God. This requires, first, that such a relationship already exists before examining the constitution of such a relationship and finally, its maintenance, development, and strengthening. His concern is for God and the individual's relationship with others. God's relationship is primarily with the individual, and not with the umma, the Islamic world as a whole, made up of individual Muslims. This communal relation has no influence on God's relationship with individuals and Khorchide rejects any form of salvation as a member of a particular society, or any effectiveness in the intercession of Muhammad or the martyrs on the Day of Judgment [Khorchide 2014a; §8.23; 37.8]. ${ }^{20}$ The relationship between God and the human person is governed by the latter's free will, which requires that the latter takes responsibility for her/his actions.

Khorchide accordingly views human development as taking place within boundaries put in place by God: human free will, rational thought, the power to make decisions, and the responsibility for what eventuates. A person may enter into a dialogue with God when s/he initiates a relationship with the

partners from discourse which would reveal the falsity of a dialogical perspective. Khorchide (as al Ghazali, Nasr Hamid Abu Zayd, Fazlur Rahman, Nurcholish Majid, Muhammad Arkoun and others before him) were charged with heresy in order to strip them of the authority to engage in the discourse about the nature of Islam. Hence these thinkers are aware of the processes of marginalisation and the necessity to continue offering alternative approaches to religious thought.

19 Submitting to the flow of divine love can be hampered by pride. However, Khorchide also refers to Ghazali's categorisation of small shirk (e.g. to follow false authorities). He does so in order to argue for the actions and thoughts that put distance between humans and God [Khorchide 2013b].

20 "In order to protect the freedom and sovereignty of man, Islam strictly rejects any form of mediation between man and God in the shape of institutions, clerics, masters, etc. The Qur'an's criticism of the Meccans, who have argued that they worship idols next to God in order to get closer to God (Quran 39: 3), can today be applied to any form of selfabandonment. Any form of permitting paternalism is a participation in the robbery of one's own freedom which is wanted and given to man by God and therefore stands in clear contradiction to the Islamic faith itself" [Khorchide 2015; §7.13; 46.9]. 
page 15 of 31

Divine and when s/he turns the inclination of the heart towards the Good. Khorchide thus defines Muslim belief as a synthesis arising from a loving relationship between the Other and the believer and its effect on the life and actions of the believer. It is this process which Khorchide calls the perfecting of humanity. ${ }^{21}$ The process provides the incentive to practise a godly life; to be close to God; and to accept the gracious offer of mercy without expectation of an afterlife of rewards. Already in dunya (the temporal world) the life of the just is being lived in so far as one's actions are performed out of joy and not fear. Communion with God shapes a positive attitude towards life and one's acts are performed out of love of God and of the Other. In God's dealings with humanity respect for all creatures is shown and God's wish is that we should pursue the good as free agents in accordance with our wills and in order to gain perfection. Rewards and punishments as concepts mentioned in the Quran, are to be understood as a pedagogical instrument, a threat or reward of the sort that parents use out of love, concern, and responsibility for their children. In essence, neither reward nor punishment reflects God's real intention. What the Divine cares about is that humanity strives for perfection in order to be able to experience eternal joy in the its presence.

This is precisely how God deals with us. He respects us, He wants us to pursue the good as free agents, according to our own will, in order for us to gain perfection. The concept of reward and punishment, as it is mentioned in the Qur'ân, is to be understood as a pedagogical concept, reflected in the way a father threatens his children with sanctions out of love, responsibility and concern.

Essentially, neither reward nor punishment reflect God's real intentions. What $\mathrm{He}$ cares about is that people strive for perfection in order to join Him; ultimately, God wants us to experience eternal joy in His presence. [Khorchide 2014a; §12.3; 75.0]

Again we find here a pedagogical incentive, now describing educational concepts based on reward or punishment as not ideal. God only implemented those measures, as stated in the Quran, as a temporary tool not as ideal concepts. To better understand the conditions for dialogue which arise from Khorchide's theology we must keep in mind that it is, in contrast to other, static theologies, a process theology enunciating a dynamic view of Islam

\footnotetext{
${ }_{21}$ He portrays 'human perfection' in more detail in Khorchide [2013a; 78].
} 
page 16 of 31

[Khorchide 2014a; §38.3; 268.4]. Harmony between belief and act is a precondition for a Creation in progress by reasons of what its inhabitants do in their approach to the good in alignment with God's intentions.

\section{Khorchide's Contribution to Collaborative Dialogue}

The implications contained with Khorchide's TM may now be brought within the limits imposed upon dialogue between religions. As he offers definitions of what it means to be a Muslim in both the narrow and broad sense, the dialogue between religions might possibly have been expanded into interpersonal dialogue with persons of good will in general. Nevertheless, it still appears advisable to look at the differing philosophies brought to interreligious dialogue and their varying premises, expectations, goals, and methods.

TM aims at a relationship of dialogue with God, developed and maintained through a process of mïthāq (eternal covenant) as well as other means (Qur'ān citation, ilham, waḥy, and ayat). This enables the relationship between God and human beings to develop on terms of equality and also seek interaction between humans, which furthers a positive outlook for justicefilled lives and universal salvation. TM also has significance for an Islamic pedagogy which Khorchide and his colleagues attempt to develop from the relationship between God and humankind. In Khorchide's academic sphere there is a teacher-student relationship that is based on patience, forgiveness, and hope. Possibly in the future this style of teaching, communicated to pupils in schools and students at universities, may influence, for the better, dialogue between national and cultural groupings in the workplace.

This model of dialogue, derived from TM, would seem to be a good candidate for creating welcoming spaces for all who enter them. As it reveals the inclusiveness of God, the Other, and God's intention to communicate with all human creatures by addressing them through the Qur'ān, the stream of love is provided to all. Only pride, self-centredness, overweening selfconfidence, forms of shirk that distance one from God's love and mercy, 
page 17 of 31

would exclude a person from this relationship with the Other [Khorchide 2013b; 69]. For those of other faiths and non-believers, any elements within their systems of belief and weltanschauung that create this distance, must be reflected upon and commitment made to the re-establishment of modes of living in harmony with love and mercy [Khorchide 2013a; 78].

To summarise: TM promotes meaningful dialogue between humanity, is based on a relationship of dialogue between God and human beings, is of academic significance and provides a practical basis for the inclusion of all humans in God's eternal love and communion. At the same time, TM reinforces a soteriological inclusiveness which allows for the co-operation in the human community of the work of salvation, work which can be considered from several points of view, not only inclusive, but also exclusive, pluralistic, and involving dialogue. As a final reflection the implications of TM for practising dialogue will be linked to Catherine Cornille's five pillars for interreligious dialogue.

To begin we shall examine the work of salvation from an exclusivist point of view; that of the adherents of a religious tradition which regards itself as without error and views all others as fundamentally flawed and unable to provide a way to salvation except in exceptional circumstances-the adherent must, for instance, be afflicted with an invincible ignorance of the nature of true belief. These constructs are, of course, the creation of those who promote them and the various levels of divine acceptance which they postulate are quite arbitrary. It is certainly correct to state that soteriological exclusivism arises from a search for a strong sense of identity and a perceived lack of alternative options. It also manifests an equally strong sense of the erroneous nature of the religious beliefs which the partner in the dialogue must abandon, displaced as he or she is by not being an adherent to the 'right' tradition. The boundaries set by exclusivist theological positions do not therefore leave space for a dialogue entered into on terms of equality which grants each side options of doubt as well as openness to alternative explanations of the world. In the Islamic context: 
Soteriological religious exclusivists [...] tend to look to Qur'anic critiques of the 'People of the Book,' 56 verses which strongly condemn the 'unforgivable' sin of Shirk (associating partners with God), 57 and verses such as Q. 3:19 and 3:85, which speak of 'islām' being the only acceptable path [Khalil 2007; 14].

The narrative of Islam uses faith content to define belief and non-belief. For Khorchide this viewpoint disregards the overall message of the Qur'ān-God's universal mercy and justice. Qur'ānic texts, secondary sources such as hadith, sira, and fiqh, and any weltanschauung not in agreement with the principle of justice for the sake of the common good, and which is not in harmony with God's ever unfailing love and mercy, none of these should set the standards for our living in the world. For Khorchide the text of the Qur'ān as a basis for a contemporary Islamic theology allows for inclusivist, pluralist, and dialogic views of the world but not exclusivist:

Exclusivism completely rejects other points of view. The Qur'ān does not contain any explicit examples of this. Nevertheless, very often advocates of this school of thought invoke the following Qur'ānic verse to back up their opinion, "The [true] religion with God is Islam." They fail to understand that the term "Islam," as it is used in the Qur'ān, does not refer to a specific religion; it stands for believing in the one God. Amongst others, Abraham, Lot, Noah and Jesus' disciples are all referred to as Muslims in the Qur'ān. [Khorchide 2014a; §47.9; 324.3]

Khorchide, as we know, goes even beyond the Quran in this instance, defining Islam in a different and broader sense, not necessitating the belief in God or the Prophet for that matter.

Inclusivism, on the other hand, looks to God's universal handiwork found throughout all forms of being and made for humanity in its entirety. In inclusivism religions can be seen as different paths towards a common goal and their adherents as collaborators in their quest for communion with the love of God [Moyaert 2012; 6]. To show that the Qur'ān permits an inclusivist understanding of the possibility of salvation for those who do not follow Islam, Khorchide has this to say:

Inclusivism recognises and respects other points of view but judges them according to its own criteria. Respect for the other side is conditional and these conditions are defined by one's own belief system. One example would be the answer which was revealed when a Persian Companion of the Prophet Muhammad, called Salmān alFārisī, asked about the truth behind the beliefs of some of his friends, who belonged to a different group of faith:258 "The believers [Muslims], the Jews, the Christians 
and the Sabians - whoever believes in God and the Last Day and does what is good, shall receive their reward from their Lord. They shall have nothing to fear and they shall not grieve." 259 This verse lists all the religious groups known to the original target group for which the revelation of the verse was first intended. According to this verse, no religious group was to be excluded from salvation, but everyone had to fulfill the key criteria of Muslim faith: i.e. believe in God and judgment day and do good deeds on earth. [Khorchide 2014a; §47.7; 323.1]

Inclusivist and pluralist attitudes with regard to religion, salvation, and dialogue are similar in their search for a 'common ground,' however much they differ in their understanding of how to base their interactions upon it. This means the pluralist does not necessarily establish a common highway that leads to salvation but leaves each person in the dialogue to take his or her separate paths. On the other hand the inclusivist defines a common ground to which all others will be summoned, which seems to be closest to what Khorchide's TM provides.

The Pluralist, of whom John Hick is an example, postulates that there might be a common reality which is the basis of all religious expressions concerning the Divine, see Khalil [2007; 21] and Moyaert [2012; 6]. This means that the pluralist model as a basis for dialogue does not focus on the particulars of each tradition but on commonalities. As Moyaert describes it: "In short, the emphasis lies more on the unity, universality, and commonality, and less on the plurality, the difference, or the specificity, of the various religions" [Moyaert 2012; 9]. For her a 'good theology' applies hermeneutical openness as a necessary tool for 'real dialogue,' in the context of comparative theology. She refers to Gadamer's hermeneutical circle which enables a transformation of one's perceptions, the melting away of horizons of the partners in the dialogue whether they be person, artwork, or text. The ideal outcome of a dialogue within such hermeneutical openness is the discovery of new meanings for both participants [Völker 2017; 172]. ${ }^{22}$

${ }_{22}$ Nasr Hamid Abu Zayd also never tired of pointing out the life-changing forces of engaging with human beings, texts, music and artwork, with reference to Gadamer's hermeneutic. 
page 20 of 31

Moreover, Khalil mentions attempts by Islamic pluralists to appeal to scripture in support of the salvation of non-Muslims, besides various attempts to marginalise or exclude their interpretations.

Indeed, Islamic scripture seems to allow for a wide variety of readings. For example, soteriological religious pluralists, who have employed arguments similar to those of evangelical Christian-turned-pluralist John Hick, will often cite verses such as Q. 2:62 and 5:69, which appear to speak of righteous Christians, Jews, and 'Sabians' 54 (i.e. the 'People of the Book' [Ahl al-Kitāb]) being rewarded in the afterlife. But then the question becomes, Are these references to those living in a post-Muhammadan world who choose to reject the final Message while maintaining their respective faiths? As Mahmoud M. Ayoub would have it, Q. 2:62 "is one of many general statements in the Qur'an in which faith is raised above any religious or ethnic identity." Nevertheless, he goes on to note that exegetes have sought to limit its universal application in several ways. Four main approaches may be distinguished. The first was to declare the verse abrogated and hence inapplicable. The second was to limit the application of the verse by assigning the reason for its revelation to a specific group of people. The third approach has been to limit the verse to a strictly legalistic interpretation, and the fourth has been to accept the universality of the verse until the coming of Islam, but thereafter to limit its applicability only to those who hold the faith of Islam. [Khalil 2007; 14]

From the start, Khorchide emphasises that scriptural material about nonMuslims is scarce and historically contextualised, and too partial to embrace a holistic stance on the religious Other [Khorchide 2014a; §47.3; 321.8]. For example, Khorchide writes “the Qur'ān does not contain one clear message defining a uniform attitude towards Jews and Christians. The Qur'ān was revealed in different contexts; for each of these contexts it provides the correct option, resulting in various different options" [Khorchide 2014a; $\S 47.12 ; 325.1]$. Hence the contemporary Muslim is left with the hermeneutical task to define attitudes towards the religious Other. ${ }^{23}$ In support of the pluralist stance, Khorchide translates Q 109:6: “I do not worship what you worship, nor do you worship what I worship; Nor do I worship what you have worshipped, nor do you worship what I worship. You have your religion and I

23 "In order for inter-religious dialogue to lead to a better understanding between different religious groups, we need to understand "the other side" within its own logic; stigmatising them based on our own belief system will lead to nothing. Qur'ānic passages about Jews, Christians and members of other religious groups reflect attributions made by different religious groups on the Arabian Peninsula during the seventh century, based on their own beliefs. It is impossible to derive universal propositions about other religions from these passages, which would then be valid for all times." [Khorchide 2014a; §45.2; 316.8] 
page 21 of 31

have mine." However, he cites this verse more in support of tolerance towards others and does not touch upon the topic of a common ground (such as, for example, the one and only transcendent being).

In her understanding of a pluralist interpretation of inter-religious dialogue Marianne Moyaert mentions following four pillars: commonality, deabsolutisation of truth, mutuality between dialogue partners, and dynamic understanding that enables openness for the Other [Moyaert 2012; 8]. Khorchide's TM may be described as a pluralist-dialogical model of Islam since it establishes the common ground of God's eternal love for all; identifies pride and its manifold consequences as creating distance between humans and divine love; allows for inclusivist, pluralist and dialogical encounters with others; and calls for the necessity of coming to a mutual understanding of the other's religious beliefs and weltanschauung.

Next to inclusivism and pluralism, Khorchide likewise identifies a dialogical stance towards non-Muslims from within the Quranic text.

Within the framework of a dialogical approach, other points of view are not only recognised; others are approached and consulted in order to understand and respect their logic. A dialogue is taken up with the objective of learning from the other side, and of offering them an opportunity to get to know one's own belief system. The following Qur'ânic invitation, presented to the Roman emperor by the Prophet Muhammad's messenger, can be taken as an example for this, "Say: 'O People of the Scripture, come to a word common between you and us, that we worship none but God.'” [Khorchide 2014; §47.11; 324.7]

He understands dialogue as a meaningful exchange of information about one another's faith, as part of a learning process about the other's religion. In this instance he does not point to the possibility of an enrichment of one's own religious understanding and tradition. The common ground is, however, set by the one God, transcending other monotheistic religions (as implied here by the Quran). The dialogical character emphasised by Khorchide is also present in the composition of the Qur'ān as "the result of dialogue, debate, argumentation, acceptance and rejection" [Khorchide 2014a; §43.2; 303.0]. ${ }^{24}$

${ }^{24}$ Khorchide refers here to Nasr Hamid Abu Zaid, Gottes Menschenwort. Für ein humanistisches Verständnis des Koran, (God's Human Voice. A Humanitarian Approach to the Qur'ān), Freiburg/Basel/Wien 2008. Abu Zayd's Algerian-French colleague, Muhammad Arkoun, further emphasized that the Quranic text is a product of arbitrary distortion, omission and selection. Abu Zayd also mentions "that the term mușhaf has as root shf, 
The dialogical model that "sees religion as the expression of" that relationship [Khorchide 2014a; §21.1; 127.0] can be derived not only from the Quran but also from the dialogical relationship "between God and humanity." Therefore, the dialogical aspect of existence within creation receives immanence:

Our modern world needs a theological approach which defines the relationship between God and humanity as a dialogical and free relationship. Within such a relationship, God's only means of winning people's love, and therefore of finding people who join Him in His love, are love and mercy. This is the ultimate goal of creation and the focus of God's actions. [Khorchide 2014a; §53.5; 379.0]

As the Quranic material contains mostly contextualised information about nonMuslims, Khorchide compiled a set of six principles for dealing with nonMuslims, derived from universal passages of the Quran: 'Human dignity is inviolable; religious diversity reflects God's will; only God can and may judge humanity; Islam is not the only path to eternal joy; human beings are to treat others justly and with kindness; there is freedom of religion': "These six guiding principles form a framework and represent guidelines for the way in which Muslims should treat people representing different groups of faith and outlooks in life" [Khorchide 2014a; 47.2; 333.8].

In bringing to a conclusion Khorchide's treatment of Islam as possibly inclusivist, pluralistic, and dialogical I shall summarise briefly his ideas on the formation of values which he presents as a collaborative venture. Values, Khorchide holds, develop within dialogue. Islam, provided that it is not institutionally ossified, has the resources to contribute to the development of common values in correspondence with a pluralistic German society. God seeks a dialogue not only with adherents of religions but with the entire human society, a perspective consistent with what already found, namely that TM does indeed address all humanity. When it comes to values as a basis for ethical norms he sympathises again with the Mutazila who favoured the discernment of values through rational operations. Good and evil are not preconstituted by God, who gave humans free will and thought to determine what

which is the root for sheet (Blatt) but also for the word distortion (Entstellung)," which might explain the suspicion of the early Muslim Arabs towards the written word (cf. Abu Zayd, Ein Leben mit dem Islam, 24) [Völker 2017; 40-42]. 
page 23 of 31

adds to the common good and what harms it. God only gave guidance towards a just society for everyone. Therefore everyone, not only religious people or religions, can develop criteria for ethical values. With regard to Islam this means that is a divine instrument installed by God to help creation develop further values towards the Good and to strengthen those that have already been established. With regard to the existence of differing religions, Khorchide cites the Quran saying "To every one of you We have appointed a right way and an open road" (Q 5:48), hence God provides multiple paths. ${ }^{25}$ Hadith sayings, according to Khorchide, support the view that Islam is open to all values and practices not contradictory to the Commandments. He also emphasises, citing Ghazali, that values are created through a combination of emotional and rational processes. This means that the heart is identified as the centre of ethical knowledge (Erkenntnis), 'the true essence of humankind.' [Khorchide 2014b; 595]. Within it reflection and improvement take place, which add to the self-knowledge which marks the beginning of the creation of values. Self-knowledge (Selbst-Erkenntnis) he establishes as essential for advancing towards Divine Knowledge. In other words, generating values is one pillar of the love-action harmony.

25 The Arabic word here is sir'a, which can be translated as cult or rite (e.g. R. Paret), and shares its root $\hat{s} r$ with the word sari'a which means the place 'where the water runs' or 'the straight path'. Hence sir'a carries the metaphorical connotation of 'path' (cf. [Schulze 2015; 535].

Douglas Pratt has pointed out that the nature and outcome of dialogue between Christianity and Islam, for example, depends on the degree to which the partners hold on to the belief that the prescribed way to salvation and truth of their religion is exclusive. He instead suggests that the outcome of a fruitful encounter between religions might be "a new way of being" that does not entail the belief in only one right type of religious creed: "[...] that the God present in Jesus manifests the values and dynamics of love, forgiveness, acceptance, self-giving and transcendent inspiration that are not in themselves historically or contextually bounded. It is this that invites us to go beyond the boundaries of our thinking, our assumptions, whatever we regard as the religious norm. It invites us to be open to a new future, a new way of being, one which accords with and reflects the divine purpose for human creation even more authentically than we may have imagined previously" [Pratt 2014; 148]. 


\section{Final Considerations}

Khorchide's inclusivist, pluralist, and dialogic understanding of Islam is in agreement with his contribution to inter-religious dialogue. I would therefore now like to draw attention to Catherine Cornille's five pillars. 'Real' dialogue is understood by her as being mutual, meaningful, constructive, and enriching the understanding between the self and the Other and the truth and tradition of each. The pillars that such a dialogue are based on are humility, commitment, interconnection, empathy, and hospitality, and can be brought into relation with what Khorchide's TM itself has to offer. That TM allows for salvation for all humans through collaboration also lends support to the idea that TM makes a necessity of collaborative dialogue between both adherents of the various religious creeds and the wider world.

Humility might be described as a portmanteau word for 'human' and 'fallibility.' It recognises the limited abilities of humans to grasp and describe ultimate truths, gives space for growth, since it allows that one's own understanding might be insufficient to comprehend and explain divine reality. One's trust in the correctness of doctrines and the appropriateness of rites is thus opened to modification. In line with Khorchide's views, for example, is the consideration that religious rites are tools assisting believers to progress towards human perfection. However, these tools are, of themselves, neither necessary nor sufficient: it is the state of the heart and the harmony between love and action that must be the principal sources of perfection. In the context of TM the doctrinal absolute that is established is the mercy of God which Khorchide postulates as the basis for all humans striving for perfection and entry into God's presence. Despite the greatness of its goal, TM does allow for 'epistemological humility' [Cornille 2013; 22] since it allows, for all human intellectual operations, the grain of doubt and fallibility. Hence doctrines established by religious or other authorities remain subjected to liberal anarchy. In defence, TM collates the thought of predecessors such as 
page 25 of 31

Muhammad Arkoun, Fazlur Rahman, and Nasr Hamid Abu Zayd, who have promoted the application of historical-critical and social-scientific studies to Islam, its scriptures and traditions. A result of this approach is a growing critical stance towards conformity (taqlī $d$ ) and transmission of knowledge based mainly on the criterion of authenticity (naql), in contrast to being based on rational discernment ('aqI). Khorchide promotes the application of 'aql, which demands proofs, arguments and discourse, and hence a priori 'claims to superiority or exclusivity' are rejected straightaway.

The second pillar of Cornille's five: commitment is present in TM since Khorchide argues from within the faith community, being a professed Muslim and having dedicated his youth as well as his professional life to the study and teaching of Islam. He is a dedicated supporter of contemporary thinking about Islam as well as being interested in developing guidelines for living a constructive Muslim life among a non-Muslim majority. He takes on the task of trying to argue for his view on the Qur'ān and Islam by re-visiting Islamic traditions, seeking to find support in past sources. One might argue-as several of his critics do-that some of his advances are inconsistent or eclectic; nevertheless, his academic commitment has held priority over the promotion of purely personal views on Islam. Rather, he attempts to keep in line with a rich tradition of Islamic intellectual reformation. In other words, he seems to be on a mission in Islamic circles to convince others of TM. Some of the harshest critics of his influence and position, as well as more moderate critics in the established Muslim associations within Germany, question whether Khorchide has the authority to speak from within Islam for Islamsome even calling him an apostate.

This might make it more difficult for him to present TM from within his community of faith, when it comes to engagement with non-Islamic bodies. At the same time TM is considered highly valuable by outsiders, non-Muslims who have an interest in engaging in an inter-religious dialogue that gives all partners enough space to be, in truth, really as they are. So there is clearly a tension between TM's potential for inter-religious dialogue and accusations of 
page 26 of 31

lack of commitment from Khorchide's critics who consider his thought marginal and non-traditional. Such tension might indeed hamper the chance for "the fruits of the dialogue to be enjoyed by a larger community" [Cornille $2013 ; 24] .^{26}$

In terms of interconnection, TM offers the common base of human existence. Creation, as a consequence of God's mercy, renders all humans as partners in dialogue with God. The will of God to enter into dialogue with all, regardless of their religious affiliation or knowledge of Islam, is joined to a human need to plunge into the stream of God's love. Everyone has this need, which can be filled only by accepting the Divine offering. At a more basic level, all humans share certain existential questions, ask about the good life and happiness, try to answer the questions of human origin, purpose, end and what, if anything, comes after. TM mainly focuses on the shared need for living in a just society where one can also be free in thought and action, ideally in accord with the love and mercy provided. To live in a just society touches upon practical questions about justice and the common good, which should be asked and answered co-operatively. TM addresses less the hypothetical search for absolute truth, happiness, and salvation, while the latter is solved mainly by the axiom that love is provided to all and therefore the path to harmony between love and deeds, and to human perfection, is open to all. More concretely, TM supports the concept of interconnectivity

- on the basis of God's love provided to all and accessible to all;

- by the will of God to communicate with all humans (by various means: text, signs and inspiration) and the need of all humans to accept God's love; and

- by the goal of establishing just societies that enable free and open dialogue and acts directed at achieving the common good.

\footnotetext{
${ }_{26}$ There have been calls to boycott his lectures, since both students and community members consider his teachings un-Islamic or non-traditional. Their worry is that Khorchide's students, once they have graduated, will have difficulties finding appointments within Islamic communities.
} 
From these parameters we can infer that TM is open to the possibility that truth about God's mercy and love has been revealed and manifested in various other religious, humanist or intellectual traditions and endeavours.

Empathy with the religious traditions of the partners in dialogue may not be invoked solely by what each partner believes and says about the other's tradition but rather as the consequence of an inner appreciation that the other is also a recipient of, and witness to, God's love. This results in empathy superseding possible feelings of rejection of certain beliefs or practices of the partner in dialogue. A further step would be a "transposition into the mental lives of others" or "reproducing (emotionally) the experiences of others" [Cornille 2013; 27]. TM also offers empathy with the dialogue partner based on the shared experience of being God's creature and in need of acceptance of God's love. This empathy is more one arising from shared existence as a human being rather than shared religious experiences or doctrines. Since TM postulates God's mercy and love as described in the Qur'ān, hadith and Islamic tradition, empathy towards the partner and his or her tradition will depend on whether its beliefs and practices can be contained within a framework of Islamic mercy which leads to a just and free society. An "expansion of one's religious imagination and experience," as Cornille [2013; 28] says, will therefore occur in circumstances in which the dialogue partner has to offer an alternative, individual, or original understanding of the harmony between love and deeds that the Muslim partner might not have yet encountered but that is, nevertheless, in accord with the ten commandments and the prospect of achieving the common good. Empathy in the TM frame seems to rest, first of all, on an understanding of the other's agenda and an acceptance of the harmony between love and deeds witnessed in the person and life of the partner in dialogue. TM does not, in fact, contain criteria that would not allow for a Muslim to experience God's love within a rite or ceremony of a different religious tradition, or in the mutual exchange of ideas and experiences with a non-religious Other. 
This leads to Cornille's fifth pillar for inter-religious dialogue. Once a Muslim discovers that God's love is manifested in the partner's religious doctrine or rites, he or she is enabled to offer space for it to be integrated into her/his understanding and practice of Islam. Such a scenario of hospitality delivers "sufficient reason to engage that religion in a constructive dialogue" since "any single inspiring thought or practice may or should lead to a constructive engagement" [Cornille 2013; 28]. Hospitality can be practised along two lines. Following Haight (1999), Cornille sketches the operation along minimal or maximal norms and negative or positive norms respectively. Operating along maximal or positive norms means to accept "only those teachings or practices in the other tradition which are identical to one's own." The second operating line excludes "only those teachings and practices which are irreconcilable with one's own" [Cornille 2013; 29]. TM operates according to the latter norms, since it sets maslaha and observance of the ten commandments as its goals, as well as, on a broader level, harmony between word and deed as criteria for human perfection. Any ideas, doctrines, and practices which are in opposition to these goals are not to be regarded as divinely intended. While the long term basis of harmony between love and deed, and striving for the common good, are attractive ethical criteria for pluralist engagements in inter-religious dialogue, those, in practice, often come into conflict with the tenets or moral imperatives (as well as tolerances) of adherents of different faiths. However, also TM's hope for the love-action harmony does include a maximal-positive line of thought, since any acceptance of love does necessarily lead to the striving towards the common good. Hence, in the end, only those beliefs and actions that share this goal, will lead to the perfection of humankind and pave the way to communion with God.

TM holds hope for harmony between love and deeds and is inclusive of maximal-positive norms, since any acceptance of love leads ineluctably to striving towards the common good. In the end, only those beliefs and activities that share this goal, will lead to the perfection of humankind and the way to 
page 29 of 31

communion with God. It has been shown how TM accepts a global collaborative salvific outlook (through the perfection of humankind) for all people, and hence renders collaborative inter-religious and inter-human dialogue necessary, for God's working within creation through humans.

\section{References}

Arberry, A. J., 1996. The Koran Interpreted: A Translation. Simon\&Schuster.

Bendixsen, S., 2013. The Religious Identity of Young Muslim Women in Berlin. Leiden: Brill, Leiden.

Burnet, J. (Ed.), 1973. Platonis Opera I (Oxford Classical Texts). Oxford: Clarendon.

Cesari, J. (2003). Muslim Minorities in Europe: The Silent Revolution. In: Esposito, J. (Ed.), Modernizing Islam: Religion in the Public Sphere in the Middle East and in Europe, Rutgers University Press.

Cornille, C. (2013). Conditions for Inter-Religious Dialogue. In: Cornille, C. (Ed.), The WileyBlackwell Companion to Inter-Religious Dialogue, Wiley-Blackwell.

Ebstein, M. (2014). Covenant (Religious) Pre-Eternal (ahd, mithaq). In: Kate Fleet, G. K. e. a. (Ed.), Encyclopaedia of Islam, THREE, Leiden: Brill.

Fuess, A. (2011). Introducing Islamic Theology at German Universities, Aims and Procedures, Copenhagen University Islam Lecture Series.

Griffel, F., 2009. Al-Ghazali's Philosophical Theology. Oxford University Press.

Hildebrandt, T. (2007a). Between Mu'tazilism and Mysticism. How Much of a Mu'tazilite Is Nasr Hâmid Abû Zayd?. In: Camilla Adang, S. S. \&. D. S. (Ed.), A Common Rationality: $M u$ 'tazilism in Islam and Judaism, Ergon Verlag.

Hildebrandt, T., 2007. Neo-Mu'tazilismus? Intention und Kontext im modernen arabischen Umgang mit dem wieder entdeckten rationalistisch-theologischen Erbe des Islam. Leiden: Brill.

Kermani, N., 2000. Gott ist schön. Das ästhetische Erleben des Koran. München: Beck.

Kersten, C., 2011. Cosmopolitans and Heretics: New Muslim Intellectuals and the Study of Islam. London: Hurst.

Khalil, M. H. (2007). Muslim Scholarly Discussions on Salvation and the Fate of 'Others', University of Michigan.

Khorchide, M. (2010a). Auf dem Weg zu einer humanistischen Qur'ānhermeneutik. In: Hamideh Mohagheghi, K. v. S. (Ed.), Moderne Zugänge zum Islam. Plädoyer für eine dialogische Theologie, Paderborn: Schöningh.

Khorchide, M. (2010b). Die Beziehung zwischen islamischer Lehre und einer modernen Islamischen Religionspädagogik. Zur Notwendigkeit der Ausarbeitung humanistischer Ansätze in der islamischen Ideengeschichte. In: Polat M, T. C. (Ed.), Islamische Theologie und Religionspädagogik. Islamische Bildung als Erziehung zur Entfaltung des Selbst, Frankfurt: Peter Lang.

Khorchide, M. (2014b). Wertepluralismus: Wertekonses und Grunddiskrepanz. Eine muslimische Perspektive. In: Rohe, M. (Ed.), Handbuch Christentum und Islam in Deutschland. Grundlagen, Erfahrungen und Perspektiven des Zusammenlebens, Freiburg: Herder. 
Khorchide, M. (2011). Humanistische Ansätze in der islamischen Ideengeschichte als Grundlage für eine zeitgemäße Islamische Religionspädagogik. In: Ucar, B. (Ed.), Islamische Religionspädagogik zwischen authentischer Selbstverortung und dialogischer Öffnung. Perspektiven aus der Wissenschaft und dem Schulalltag der Lehrkräfte, Frankfurt: Peter Lang.

Khorchide, M., 2013a. Islam ist Barmherzigkeit. Grundzüge einer modernen Religion. Freiburg: Herder.

Khorchide, M., 2013b. Scharia. Der missverstandene Gott-Der Weg zu einer modernen islamischen Ethik. Freiburg: Herder.

Khorchide, M., 2014a. Islam is Mercy. Essential Features of a Modern Religion. Freiburg: Herder.

Khorchide, M., 2015. Gott glaubt an den Menschen. Mit dem Islam zu einem neuen Humanismus. Freiburg: Herder.

Klinkhammer, G. (2003). Modern Constructions of Islamic Identity. The Case of Second Generation Muslim Women in Germany., Marburg Journal of Religion 8: 1-16.

McCutcheon, R. T., 2001. Critics not Caretakers. Redescribing the Public Study of Religion. SUNY.

Moyaert, M. (2010). Interreligious Dialogue and the Value of Openness: Taking the Vulnerability of Religious Attachments into Account, The Heythrop Journal 51: 730-740.

Moyaert, M. (2012). Recent Developments in the Theology of Interreligious Dialogue: From Soteriological Openness to Hermeneutical Openness, Modern Theology 28: 25-52.

Nökel, S., 2002. Die Töchter der Gastarbeiter und der Islam. Zur Soziologie alltagsweltlicher Anerkennungspolitiken. Eine Fallstudie. Bielefeld: Transcript Verlag.

Pratt, D., 2014. Being Open, Being Faithful. Geneva: World Council of Churches.

Pratt, D., 2017. Christian Engagement with Islam: Ecumentical Journeys Since 1910. Leiden: Brill.

Rahman, F., 1952. Avicenna's Psychology. London: Oxford University Press.

Schulze, R., 2015. Der Koran und die Genealogie des Islam. Schabe.

Spriewald, S., 2003. Rechtsfragen im Zusammenhang mit der Einführung von islamischem Religionsunterricht als ordentliches Lehrfach an deutschen Schulen. Berlin: Tenea Verlag für Median.

Unruh, P., 2009. Religionsverfassungsrecht. Baden-Baden: Nomos.

Völker, K. (2014b). Parameters of Teaching Islam 'Freely'. In: Kolig, E. (Ed.), Freedom of Speech and Islam, Ashgate.

Völker, K. (2014a). A Danger to Free Research and Teaching in German Universities? The Case of Muhammad Sven Kalisch. In: Paul Morris, William Shepard, T. T. P. T. (Ed.), The Teaching and Study of Islam in Western Universities, Routledge.

Völker, K. (2018). Nasr Hamid Abu Zayd's Philosophy on Islam and Education. In: Smeyers, P. (Ed.), International Handbook of Philosophy of Education, Springer.

Völker, K., 2017. Quran and Reform: Rahman, Arkoun, Abu Zayd. Frankfurt: Peter Lang.

Warnecke, T. (2018). Institut für Islamische Theologie HU stimmt Islam-Profs zu, Tagesspiegel.de, 12.7.

Weber, E. (2003). Allahs Mütterlichkeit und die muslimische Nächstenliebe. Ein Essay über islamische Soteriologie und Diakonie, University of Frankfurt/ Center for Irenic Studies: Journal of Religious Culture. 
Wissenschaftsrat (2010). Empfehlungen zur Weiterentwicklung von Theologien und religionsbezogenen Wissenschaften an deutschen Hochschulen;

http://www.wissenschaftsrat.de/download/archiv/9678-10_engl.pdf. 